\title{
Effect of Cooperative Learning Instructional Strategy on Senior Secondary School Students Achievement in Biology in Anambra State, Nigeria
}

\author{
Nneka Rita Nnorom \\ Department of Science Education \\ Anambra State University, Nigeria
}

\begin{abstract}
The study examined the effect of cooperative learning instructional strategy on senior secondary school students' achievement in biology in Anambra State, Nigeria. The research design employed in this study was the quasi-experimental; specifically, pretest, post test, non equivalent control group design. A sample of one hundred and eleven (111) Senior Secondary one (SS1) students drawn from two coeducational secondary schools in Nnewi Education zone of Anambra State, Nigeria. Two research questions and two null hypotheses guided the study. An instrument known as BiologyAchievement Test $(B A T)$ with a reliability coefficient of 0.79 was adopted and duly validated by experts. Mean and standard deviation was used to answer the research questions, while the Analysis of Covariance (ANCOVA) was used to test the hypotheses at 0.05 level of significant. The results revealed that students taught using cooperative learning instructional strategy perform better in Biology Achievement Test than those taught using lecture method of instruction. There was no interaction between methods and gender on students Biology Achievement Test. Based on the result obtained, it was therefore recommended that teachers should be encouraged to use cooperative instructional strategy to teach biology and other sciences, technology, engineering and mathematics subjects in secondary schools.
\end{abstract}

\section{Introduction}

Science Education has its focus on preparing individual with appropriate skills, abilities and competencies both mental and physical to live and contribute to the development of the society. Biology education is an integral part of Science, Technology, Engineering and Mathematics (STEM) education. To achieve creativity and overall national development, teaching strategy that captures interest of secondary school students in science concepts is imperative.

Many researchers agree that the conventional lecture method does not help students, construct their own understanding and opined that the uninspiring teaching methods adopted by science teachers lead not only to low achievement in the science but also incapacitates students from developing required skills necessary for creative thinking [5], [8], [13]. The lecture method is a teaching method in which the teacher presents a verbal discourse on a particular subject, theme or concept to the learners, the teacher deliver preplanned lessons to the students with little or no instructional aides [11]. Danmole [3] noted that teachers need to employ different learning methods and strategies to ensure students understanding of scientific concepts. A shift is therefore advocated by researchers to methods that will enable the learner construct his/her own understanding [4], [15], [17]. Such methods have their roots in constructivism. This trend is learner centered and among these strategies is the cooperative learning instructional strategy.

Cooperative learning instructional strategy is the deliberate instructional use of heterogenous small groups of students who work together to maximize each other's learning [5].

Heterogeneity in grouping can be achieved by combining students of different sexes, academicability level, ages, religion among others, so that students can get beyond their initial stereotypes and be able to treat each other as other science students' and fellow group members [5]. Cooperative learning is theoretically based on the work of psychologists like Levi Vigotsky, Jean Piaget among others, who proposed that children actively construct knowledge in a social context [2]. Individual performance is deemphasized while team work is promoted. Students are not simply taken information or ideas; they are creating something new with the information and ideas. These acts of intellectual processing of constructing meaning are crucial to learning.

Various researchers [5], [7], [14] have revealed the positive attributes of cooperative interaction among students as follows: more students learn more materials when they work together cooperatively; more students are motivated to learn the material when they work together cooperatively than when they compete with one another, and also, students develop more positive attitudes to science when they work together cooperatively than when they work alone.

Also researchers do not agree on sex influence on students' interest in science. The likes of Anaekwe 
[1] believe that sex has no influence on students interest in science. While Njoku [9] and Nwachukwu [10] opined that there are sex related differences in chemistry interest and performance. A lot has been done to improve science teaching in secondary schools in Nigeria, in spite of that, students continue to perform poorly in science subjects of which biology is one [11], [16]. This situation has created the need for more effective teaching methods. Therefore the study examined the effect of cooperative learning instructional strategy on senior secondary school students' achievement in biology in Anambra State, Nigeria.

\section{Purpose of the Study}

The purpose of this study is to determine the effect of cooperative learning instructional strategy on students' achievement in biology. Specifically, the study sought to determine:

- The differential effects of cooperative learning instructional strategy and conventional lecture method on students' achievement in biology.

- The effect of cooperative instructional strategy on male and female students in biology achievement test.

\section{Research Questions}

The following research questions guided the study:

- What is the effect of cooperative learning instructional strategy and lecture method on biology achievement test?

- What is the effect of cooperative instructional strategy on Biology Achievement Test of male and female students?

\section{Hypotheses}

The following null hypotheses were tested at 0.05 level of significance:

- There is no significant difference in the mean scores of students taught using cooperative learning instructional strategy and those taught using lecture methods.

- There is no significant difference in the mean scores of male and female students taught using the cooperative learning instructional strategy.

\section{Method}

The quasi experimental, non equivalent pre-test, post-test, control group research design was used for the study. A sample of one hundred and one (111) senior secondary one (SSI) students drawn from 17 co-educational secondary schools in Nnewi Education zone of Anambra State, were used for the study. The sample simple random sampling technique was adopted in drawing the sample. Only two schools were randomly sampled due to the experimental nature of the study. One of the schools was assigned to experimental treatment and the other one was assigned to control group. In each of the schools sampled, a stream of SSI was randomly sampled for experimental treatment and control respectively.

The instrument used for data collected was Biology Achievement Test (BAT) constructed by the researcher based on the biologytopics of Animal Nutrition and Excretion taught which was part of SSI biology curriculum. The validation of BAT was done by two specialists in science education from the university who are experienced science teachers. Split half reliability technique was used to estimate the reliability of the BAT. The score were correlated using Spearman Rank Order coefficient of correlation. The split half reliability coefficient was found to be 0.79 .

\section{Experimental Procedure}

The regular biology class teachers were used for the study in both experimental and control groups. Before the experiment in each of the sampled schools, the students' continuous assessment and terminal examination scores were used to stratify the students into ability group (high, middle and low). Then, groups of mixed abilities were formed in the class. Training was given to the biology teacher who took the experimental group on the application of the instructional approach, while the biology teacher who took the control group used the conventional method. The teacher explained the features and practice of cooperative learning instructional strategy to the students. The lecture method was used in the control group without stratifying the students. The experimental class teacher was given note of lesson prepared by the researcher while the researcher vetted the lesson plan prepared by the biology teacher in the control group to ensure that the teacher did not deviate from the procedures of instructions commonly used by biology teachers. Biology achievement test (BAT) was used for both pre-test before treatment and post-test after treatment.

The treatment consisted of teaching the selected biology concepts of animal nutrition and excretion using cooperative learning instructional strategy. This involved teaching the biology concepts through the use of materials to concretize learning, providing opportunity for students to interact among themselves and work together with materials in the environment cooperatively as they try to find answers to problems encountered while learning the biology concepts. The control group was taught the same biology concept using lecturer method. 
The teaching lasted for 4 weeks. Each teacher in the experimental and control schools was expected to complete the teaching of the biological concepts following the stipulated guidelines. Immediately after the completion of the teaching of the biological concepts, the BAT was again administered to the students (after reshuffling) as post-test and scores were recorded.

The data were analyzed using mean and standard deviation for answering the research questions, and Analysis of Covariance (ANCOVA) was used for testing the hypotheses at $0.05 \%$ level of significant.

\section{Result}

Research question 1: What are the effects of mean scores of students taught using cooperative learning instructional strategy and those taught using lecture method on BAT?

Table 1: Mean and standard deviation for the experimental and control group

\begin{tabular}{llllllc}
\hline & & \multicolumn{2}{c}{ Pretest } & \multicolumn{2}{c}{ Post test } & $\begin{array}{c}\text { Mean achievement } \\
\text { gain }\end{array}$ \\
\cline { 3 - 7 } Groups & N & Mean & Std Dev. & Mean & Std Der. & \\
Treatment & 43 & 8.1461 & 2.91171 & 17.3559 & 2.74551 & 9.22 \\
Control & 68 & 7.1571 & 2.31337 & 10.6613 & 2.67420 & 3.51 \\
Mean & & .9890 & & 6.6846 & & \\
Difference & & & & & & \\
\hline
\end{tabular}

Table 1 shows that the experimental pretest and post test mean scores are 8.1461 and 17.3559 with standard deviation scores of 2.74551 and 2.67420 respectively. Also, the control group has pretest and post test mean scores as 7.1571 and 10.6613 with standard deviation scores of 2.74551 and 2.67420 respectively. The mean achievement gain for the treatment group was 9.22 while the mean gain in the control group was 3.51 indicating the superiority of treatment group over the control group.

Research question 2: What are the effects of cooperative learning strategy on BAT of male and female students?

Table 2: Mean and standard deviation for the experimental and control group across the sex

\begin{tabular}{|c|c|c|c|c|c|c|c|}
\hline & & & \multicolumn{2}{|c|}{ Pretest } & \multicolumn{2}{|c|}{ Post test } & Mean achievement \\
\hline \multirow{5}{*}{$\begin{array}{l}\text { Group } \\
\text { Treatment }\end{array}$} & Sex & $\mathrm{N}$ & Mean & Std. Dev. & Mean & Std. Dev. & \\
\hline & Male & 23 & 8.2174 & 2.64500 & 17.521 & 2.7281 & 930 \\
\hline & Female & 20 & 8.0556 & 3.29835 & 17.166 & 2.8336 & 9.11 \\
\hline & Mean & & .1618 & & .3550 & & \\
\hline & Difference & & & & & & \\
\hline \multirow{2}{*}{ Control } & Male & 36 & $\begin{array}{l}6.8378 \\
75152\end{array}$ & $\begin{array}{l}2.23002 \\
238644\end{array}$ & $\begin{array}{l}10.891 \\
10424\end{array}$ & $\begin{array}{l}2.1315 \\
3.1920\end{array}$ & $\begin{array}{l}4.05 \\
2.91\end{array}$ \\
\hline & $\begin{array}{l}\text { Mean } \\
\text { Difference }\end{array}$ & & $\begin{array}{r}.5152 \\
-1.3226\end{array}$ & & .4677 & & \\
\hline
\end{tabular}

Table 2 result shows that the pre test mean score and standard deviation score for the experimental male and female are 8.2174 and 2.64500;8.0556 and 3.29835 respectively. Similarly scores for the experimental male and female groups are 17.5121 and $2.7281 ; 17.166$ and 2.8336 respectively. Also, the pretest mean scores and standard deviation scores for the control male and female are 6.8378 and $2.23002 ; 7.5152$ and 2.38644 respectively. Also, the post test mean score and standard deviation scores for the control male and female are 10.891 and $2.1315 ; 10.424$ and 3.1920 respectively. The mean achievement gain for male and female in the treatment group are 9.30 and 9.11 respectively. In the control group the gains are 4.05 and 2.91 respectively for male and female.

Table 3: Test of interaction between methods and gender on students BAT

\begin{tabular}{lll}
\hline Groups & $\begin{array}{l}\text { Treatment } \\
\text { (mean gain) }\end{array}$ & $\begin{array}{l}\text { Control } \\
\text { (mean gain) }\end{array}$ \\
\hline Male & 9.30 & 4.05 \\
Female & 9.11 & 2.91 \\
\hline
\end{tabular}

From table 3 result, the mean achievement gains are higher at the two levels of gender (male and female) in the treatment group than in the control group. This implies that there is no interaction between gender and methods on students BAT.

Table 4: Summary of ANCOVA

\begin{tabular}{lllllc}
\hline Source of variation & Sum of square & Df & Mean square & F & Siguificant \\
\hline Corrected model & 1163.893 & 4 & 281.223 & 37.132 & .000 \\
Intercept & 2006.860 & 1 & 2006.860 & 268.721 & .000 \\
Pretest & 1.069 & 1 & 1.069 & .144 & .704 \\
Group & 1093.984 & 1 & 1093.984 & 147.009 & .000 \\
Sex & 4.522 & 1 & 4.522 & .607 & .436 \\
Group sex & .132 & 1 & .132 & .018 & .874 \\
Error & 788.788 & 106 & 7.441 & & \\
Total & 21131.000 & 111 & & & \\
Corrected total & 1.953 .693 & 110 & & & \\
\hline
\end{tabular}

Table 4 result show that $\mathrm{F}$ (147.009) is significant at .000 for the methods, at 1 and 110 degree of freedom (DF). This is because .000 is less than .05 significant level set for the hypotheses. Hence, Hol is not accepted. There is a significant difference between the mean achievement scores of students taught using cooperative learning instructional strategy and those taught using lecture method. Also, table 4 shows $\mathrm{F}$ (.607) is not significant at .436 for the sex at 1 and 110 degree of freedom (df). This is because .437 is more than .05 significant earlier set for hypothesis. Therefore, the hypothesis Ho2 is accepted. That is there is no significant difference between the male and female mean score on BAT.

\section{Discussion}

The findings of this study as prescribed in table I indicated that students taught with cooperative learning instructional strategy perform better than those taught using lecture method. This result is in line with Igboanugo [5] who reported that cooperative learning is more efficacious in capturing students' interest than conventional teaching method in difficult chemistry concepts. In the case of gender, the ANCOVA result reveals that there is no significant difference between the male and female students mean score on BAT. This result is 
inaccordance with Nwagbo and Chikelu [11] who found no significant difference in the achievement of male and female students in science subjects.

Again, there was no interaction between teaching methods and gender on students BAT as indicated in table 3. This result agrees with Iloputaife [6] and Nwagbo and Chikelu [11] who found no significant interaction between instructional method and gender on performance in science subjects.

\section{Conclusion}

The findings of this study revealed that students taught using cooperative learning instructional strategy perform better in biology achievement test than those taught using lecture method. Also, there was no interaction between methods and gender on students' biology achievement test.

\section{Recommendations}

Based on the findings, of the study the following recommendations are proffered:

- Teachers should be encouraged to use cooperative instructional strategy to teach biology and other science, technology, engineering and mathematics subjects in secondary schools.

- In service training in the form of workshops, conferences, seminars should be organized by governments to equip teachers to incorporate cooperative learning instructional strategy in science teaching.

- Science educators and curriculum planners should incorporate innovative pedagogical strategies like cooperative learning instructional strategy into their various teacher education programmes.

\section{References}

[1] Anaekwe, M.C., (1997). Effects of students interaction patterns on chemistry.Unpublished doctorial dissertation, University of Nigeria, Nsukka.

[2] Conway, J., (1997). Educational technology effects on model of instruction copland. http://coplandudeedu/ conwayeds $66 \mathrm{htm}$.

[3] Danmole, B.T., (2011). Emerging issues on the universal basic education curriculum in Nigeria: Implications for the science and technology component. Pakisin Journal of Social Sciences. 8(1) 62-68.

[4] Epstein, M., (2002). Constructivism" Maureen Epstein online Research Portfolio. Online, http://tiger.towsoneEdu/ mep/researchpaper.htm.

[5] Igboanugo, B.I., (2013). Effects of peer teaching on students achievement and interest in difficult chemistry concepts. International Journal of Educational Research. 72(2) 61-71.

[6] Iloputaife, L.N., (2001). Effect of analogy and conceptual change instructional model on physics achievement among secondary school students. Unpublished Ph.D thesis, University of Nigeria, Nsukka.

[7] Johnson, D. W. \& Johnson, R.T., (2002). The cooperative learning research works: college of education and human development, University of Minnesota. http://www.cooperative learning-research work-college of education and human development (University of Mina).Mnt.

[8] Kolawole, E.B., (2007). Effects of competitive and cooperative learning strategies on academic performance of Nigerian students in mathematics.Journal of Educational Research and Review 3(1) 33-37).

[9] Njoku, Z.C., (2008). Development and prelinary validation of a scale for the assessment of students activities. Journal of The Science Teachers Association of Nigeria 38 (1\&2).

[10] Nwachukwu, C.O. (2008). Correlating the cognitive achievement and interest of girls in science discipline using co-operative learning strategy.Multi disciplinary journal of research development 10 (2) 10-17.

[11] Nwagbo, C. \& Chikelu, U.C., (2011). Effects of Biology Practical activities on students process skill acquisition. Journal of Science Teachers Association of Nigeria 46(1) 58-70.

[12] Ogbonne, U.T. \& Offorma, G.U., (2013).Effects of collaborative learning method on secondary student interest in English language tenses.International Journal of educational Research 12(2) 28-135.

[13] Oke, M. (2005).An overview of some practical approaches/teaching strategies for teaching and learning of genetic concepts.STAN Biology Panel Series.7-10.

[14] Panitz, T., (2008). The case for student centered instruction via collaborative learning paradigms. Online 19/9/2009.

[15] Samba, R. M. O., Eriba, J., (2012). Innovative approaches in teaching difficult science concepts. Markurdi: Destiny ventures.

[16] Samba, R.M.O. \& Lortim, O.S., (2014).Using cooperative learning instructional strategy to foster social skills in senior secondary biology students in Benue State: A bed rock for creativity.55th annual conference proceeding of Science Teachers Association of Nigeria.207 -222.

[17] Samba, R. M. O., Achir, E. E. \& Ogbeba, J., (2010). Teacher awareness and utilization of innovative teaching strategies in Benue state. Nigeria Educational Research 1(2) $032-038$. 